\title{
CADRE EMPOWERMENT MODEL FOR EARLY DETECTION AND INTERVENTION OF PREGNANCY RISK IN SLEMAN DISTRICT, YOGYAKARTA
}

\author{
Istri Yuliani ${ }^{1)}$, Bhisma Murti $^{2)}$, Endang Sutisna3), Tedjo Danudjo Oepomo4) \\ ${ }^{1)}$ Diploma III Program of Midwifery, Respati University, Yogyakarta \\ ${ }^{2)}$ Masters Program in Public Health, Sebelas Maret University \\ 3)Department of Public Health, Faculty of Medicine, Sebelas Maret University \\ 4)Department of Obstetrics and Gynecology, Faculty of Medicine, Sebelas Maret \\ University
}

\begin{abstract}
Background: Maternal Mortality Rate (MMR) is an important public health issue in developing countries. Current MMR in Indonesia amounted to 359 deaths/ 100,000 live births, which was higher than neighboring countries in Southeast Asia. Efforts to reduce MMR by empowering cadres are believed to be effective for reducing MMR. This study aimed to identify cadre's empowerment model that explain factors associated with cadre's early detection and intervention of pregnancy risk in Yogyakarta.

Subjects and Method: This was an analytical observational study using crosssectional design, supported by qualitative information. The study was conducted in Sleman District, Yogyakarta, from February to May 2016. A total sample of 269 active cadres were selected for this study by multistage cluster random sampling. The dependent variables were cadre's early detection of pregnancy risk factors and intervention to address the problem. The independent variables included attitude, experience, motivation, compensation, workload, education and training, supervision, perceived seriousness, and perceived benefit. The data were collected by a questionnaire and analyzed by path analysis.

Results: Cadre's intervention to address the problem was directly and positively affected by attitude $(b=0.55 ; \mathrm{SE}=0.12 ; \mathrm{p}<0.001)$, experience $(\mathrm{b}=0.18 ; \mathrm{SE}=0.10$; $\mathrm{p}=0.079)$, motivation $(\mathrm{b}=0.37 ; \mathrm{SE}=0.15 ; \mathrm{p}=0.014)$, compensation $(\mathrm{b}=0.65 ; \mathrm{SE}=$ $0.20 ; \mathrm{p}=0.001)$, supervision $(\mathrm{b}=0.49 ; \mathrm{SE}=0.18 ; \mathrm{p}=0.008)$, and early detection of pregnancy risk factors $(b=0.29 ; \mathrm{SE}=0.05 ; \mathrm{p}<0.001)$. Cadre's early detection of risk factors was affected by attitude $(b=0.58 ; \mathrm{SE}=0.11 ; \mathrm{p}=<0.001)$, experience $(b=0.38 ; \mathrm{SE}=0.10 ; \mathrm{p}<0.001)$, motivation $(\mathrm{b}=0.63 ; \mathrm{SE}=0.14 ; \mathrm{p}<0.001)$, compensation $(b=0.68 ; \mathrm{SE}=0.19 ; \mathrm{p}<0.001)$, workload $(\mathrm{b}=0.64 ; \mathrm{SE}=0.23 ; \mathrm{p}=$ 0.005), education and training $(b=0.69 ; \mathrm{SE}=0.13 ; \mathrm{p}<0.001)$, supervision $(\mathrm{b}=$ 0.99; $\mathrm{SE}=0.17 ; \mathrm{p}<0.001)$, perceived seriousness $(\mathrm{b}=0.73 ; \mathrm{SE}=0.16 ; \mathrm{p}<0.001)$, and perceived benefit $(b=0.84 ; \mathrm{SE}=0.18 ; \mathrm{p}<0.001)$.

Conclusion: Attitude, experience, motivation, compensation, supervision, and early detection of pregnancy risk factors affect cadre's intervention to address the problem. Cadre's early detection of risk factors is affected by attitude, experience, motivation, compensation, workload, education and training, supervision, perceived seriousness, and perceived benefit.
\end{abstract}

Keywords: early detection, intervention, pregnancy risk, empowerment, cadre

Correspondence: Istri Yuliani. Diploma III Program of Midwifery, Respati University, Yogyakarta. Email: istriyuliani@yahoo.com. Mobile: +628122796697 